\title{
The Valleys Project Archive
}

Paul Cabuts

The Valleys of south Wales had been one of the most photographed areas in the world with images of the region being made by important figures in photography's history. The ambition of the Project is considered in light of earlier photographic surveys in the UK and North America. The article reflects upon the materiality of the project archive, its visibility and how it has been accessed during its existence. Not least, consideration is given to its significance as a reference point in the emergence of notions of 'Welsh' photography.

\section{Photographic Surveys In Wales}

To provide a context for this brief overview of the Valleys Project it is worth considering photographic surveys in Britain and Wales at the end of the nineteenth century. In 1889, Liverpool Amateur Photographic Association convened a special meeting to premiere 'Illustrated Boston', a collection of lantern slides received from the Boston Camera Club. After their journey across the Atlantic the slides then travelled between over twenty camera clubs across Britain. ${ }^{1}$ Similar photographic surveys were being undertaken across Britain most often as a way to enhance and promote a city's (or region's) civic prowess and identity. It is recognized that at this time, at local and national levels, there was an emergence of a particular consciousness that sought to identify and distinguish localities as unique. These early photographic surveys reveal a dislocation between ideal methodology and the realities of amateur surveying - one of the most idiosyncratic surveys was the Photographic Survey of Glamorganshire, Wales.

The Committee of the Council of the Free Library and Museum in Cardiff was a pivotal force behind the scheme, offering prizes and as an additional stimulus stipulating a strict deadline. The photographs were divided into sections illustrative of: Glamorganshire past and
1. V. L. Pollock, “Dislocated Narratives and Sites of Memory: Amateur Photographic Surveys in Britain 1889-1897", Visual Culture in Britain 10:1 (2009): 1-26. 
present; Monmouthshire within twelve miles of Cardiff; churches and chapels; Cardiff past and present, and castles, mansions, religious houses and crosses. The character of this survey was therefore being directed from the outset. ${ }^{2}$

Issues of local and national distinctiveness were keenly felt in Glamorganshire, particularly Cardiff, during this period. The 1880s onwards was a crucial phase during which a conscious effort was made to set Wales apart, albeit still within Great Britain. Key contributions to this during the period include; The Welsh Intermediary Education Act (1889); The Charter for the University of Wales (1893); Home Rule lobbied for by Cymru Fydd (1886-1896); The revival of a traditional national eisteddfod; The Honourable Society of the Cymmrodorion, a London-based society, was revived (1873).

This formative period of the photographic survey movement can been identified as one in which national identities were forged. The discourse surrounding the uniqueness of Wales and Welsh culture would be most significantly articulated in the campaign for the establishment of a National Museum and National Library for Wales during the period.

Accordingly, the extent to which a region could boast a far-reaching historical legacy, evidenced in the seat of noble families or remnants of more distant settlers, was indicative of their local identity and importance in the history and heritage of the nation. For Glamorganshire, this narrative became visible in the photographs of ancient crosses and druid sites by the keen antiquarian and Clerk of the Peace Sir Thomas Mansel Franklen. Allied to the picturesque, this emphasis on ancient and enduring subject matter was seen as integral to the cultivation of identity. ${ }^{3}$ Arguably, future photographic surveys such as the Valleys Project would also do much more than just document places, often emphasizing certain characteristics depending on the priorities of the photographers or commissioning organisations.

William Booth, a Cardiff-based photographer who was active in the 1890 s and 1900s, contributed many urban images to the Photographic Survey of Glamorgan. The focus of his photographs took a more modern turn as he illustrated life in the streets and open spaces of Cardiff during the 1890s. One of his photographs shows the 'Hotel de Marl', which was an outdoor drinking scheme devised by local men in Grangetown, Cardiff to evade the 1881 Sunday Closing Act. ${ }^{4}$ Booth's 'street photography' engaged with the contemporary social concerns of the day.

Other British surveys during the period would provide important archival material through their documenting photographs. Sir Benjamin Stone made an invaluable record of the folk customs and traditions of the British Isles, which influenced later photographers of note, including Homer Sykes, Daniel Meadows, Anna Fox and Tony Ray-Jones. Stone wrote of his purpose as being "to portray for the benefit of future generations the manners and customs, the festivals and pageants, the historic places and places of our times". ${ }^{5}$ The Benjamin Stone Photographic Collection housed in the Library of Birmingham contains many thousands of examples of his work. In 1897 he founded the National Photographic Record Association, of which he became president.

In 2015 the Library of Birmingham presented a collaborative project by artists Sophy Rickett and Bettina von Zwehl. The exhibition marks the culmination of their work based on images from the Library's Sir
2. Pollock, "Dislocated Narratives".

3. Pollock, "Dislocated Narratives".
5. "Library of Birmingham, The Way We Were", accessed December, 2015, http://www. libraryofbirmingham.com/articles/ benstonetravellersjoy/ benstonewaywewere. 
Benjamin Stone Collection, which is one of the most extensive photography archives held in the Library.

\section{Photography and Newport}

Newport School of Art and Design would become a significant driving force in the development of photographic surveys in Wales in the last quarter of the twentieth century. In 1971 the Welsh Arts Council presented Magnum photographer David Hurn with an award for 'outstanding merit in a living artist'. ${ }^{6}$ Hurn's work had, by this time, been published and exhibited internationally. Hurn's coverage of the 1966 tragedy at Aberfan was a key factor leading to him returning to make his home in Wales - he had lived in Cardiff as a child. ${ }^{7}$ In the early 1970s he was encouraged to develop a photography course at Newport where he established projects that included getting students to produce photographs illustrating big national news stories.

Photography at the time was rapidly evolving as an independent creative practice and the gradual acceptance of photography was starting to be established within the fine arts.

The desire to further develop live-brief work for students, along with the humanistic dimension of the documentary photography course, led to the development of the ambitious Newport survey, which started in 1979. This survey was considered in light of the prevailing social and economic conditions in the UK at that time and parallels were drawn with the photographs from the 1930s by the American New Deal photographers of the Farm Security Administration (FSA). The reputation of the Newport School of Art and Design's documentary photography course was considerable by this time, and part of the curriculum included a study of the FSA work. ${ }^{8}$

Throughout the 1980s, Documentary Photography students worked closely with those studying Graphic Design to document life in the town. Collectively, the Newport Survey sought to document different areas of life in Newport's changing communities during a decade of intense social change. The resulting work was published annually and also displayed within the town's Art Gallery and Museum. Whilst the policies of Thatcherism did much to generate the demise of the heavy industry in the region it would be misleading to characterize the Survey as depicting nothing but decline; on the contrary, it often showed the resilient spirit of Newport's population along with the presence of new industries such as the emerging electronics sector at that time.

\section{A photographic gallery for Wales}

In terms of the Valleys Project there is a need to briefly review the early development of Ffotogallery, the first gallery dedicated to photography in Wales. The 1970s saw creative/independent photography in Britain starting to gather momentum in its development. An exhibition of Bill Brandt's work at London's Hayward Gallery in 1970 has since become regarded as a milestone for photography in Britain. During the decade organizations such as the Arts Council of Great Britain became more supportive of contemporary, 'creative' photography fostering the development of a small number of photography-specific galleries in Britain, including the Photographers Gallery and the
6. David Hurn, David Hurn Photographs 1956-1976 (London: Arts Council of Great Britain, 1979): end cover.

7. David Hurn, Lecture, Welsh Festival of Documentary Photography (Aberystwyth: Lens, 2009).

8. Paul Cabuts, Creative Photography and Wales (Cardiff: UWP, 2012): 115. 
Half-Moon Gallery (London), Impressions Gallery (York), Open Eye Gallery (Liverpool) and the Side Gallery (Newcastle). In 1973 the Arts Council of Great Britain appointed Barry Lane as its first photographic officer.

The artist, photographer and academic Alistair Crawford produced a written description of photography's emergent Welsh dimension in 1978. Published in 'Planet' magazine, the photographer and academic outlined photography's position in Britain and suggested that there should be priority in Wales for the development of a photographic gallery for Wales in which photography and its relationship to Wales could be celebrated. Such a gallery would soon materialize.

During 1977 and 1978 David Hurn had helped organize a series of lectures on photography through the Extra Mural Department of University College, Cardiff in collaboration with the Welsh Arts Council. Sir Tom Hopkinson, one time editor of 'Picture Post', was the Director of the Centre for Journalism Studies at University College, Cardiff and a key advocate for photography in Wales at the time. The lectures drew a large popular response with guest speakers including Bert Hardy and Don McCullin. As a direct result of those lectures Oriel Ffotograffeg came into existence through the work of enthusiasts, professionals and academics.

It is perhaps no surprise that the gallery's first show in 1978 would take the form of 'Collected Photographs - Photographs from the collection of David Hurn'. The first few years would prove turbulent and difficult as the organization, largely run by volunteers, worked to professionalize itself. On the one hand volunteers would paint out the gallery on weekends buying the paint from Bessemer Road market (then the only place open on a Sunday). On the other, the ambition of Director Bill Messer to engage with European Photography would see him, along with the focus of the gallery, often some distance away from Wales. Following an acrimonious dispute, and the intervention of the Welsh Arts Council, Robert Greetham took over as Director and the organization was rebranded the Ffotogallery. As part of this process Ffotogallery restated its aims as "To promote and encourage the practice of photography in Wales. To bring photography of the highest international standard to Wales". ${ }^{9}$

The change in focus became visible in Ffotogallery's programming with exhibitions such as 'Cardiff as a Seaport' and the development of shows to be presented away from its own gallery such as 'The Welsh Landscape' for St. Donat's Art Centre, and Peter Fraser's 'Recent Colour Work' for University College, Cardiff which had an exhibition corridor for photography during the period. The photographic staff at Newport would have a significant influence on Ffotogallery's early output. Between 1981 and 1984 the gallery's management committee consisted of approximately ten members, a proportion of whom were photography staff from Newport including Ron McCormick, lan Walker, Keith Arnatt, Clive Landen, Pete Davis and Daniel Meadows. Keith Arnatt was the selector for Ffotogallery's Welsh Open Photography 1983 - the gallery's renewed focus on Wales was clearly visible at this time.
9. Robert Greetham, Ffotogallery 1976-1996 (Unpublished, 1996).

\section{The Valleys Project}

Ffotogallery continued its Wales focus with the development of a similar project to the Newport Survey, but covering a wider 
geographical area. In October 1983 Susan Beardmore became Ffotogallery's director and announced that an inaugural exhibition of the Valleys Project would take place in February 1984 and stated, "With the Valleys Project, the Ffotogallery will, over a three year period, be documenting the life and landscape of this area as fully as photographically possible". ${ }^{10}$ This first exhibition was made up of the work of sixteen contemporary photographers, a selection of historical photography, and the work of four community photography workshops.

Phase two of the Valleys Project proved distinctly different from the first, with Ffotogallery funding the contributors through commissions. Ffotogallery was one of the early photographic galleries in Britain to make a commitment to photographers, allowing them the time and creative freedom to document their subjects within an overarching brief. The commissions were awarded to Ron McCormick and recent Newport graduate Paul Reas. Rhymney Valley District Council commissioned John Davies to undertake his part of this phase - the exhibition took place early in 1985.

Later in 1985 Ffotogallery produced the publication 'Valley Visitors'. Researched and written by Newport's lan Walker it provided an insight into the range of key photographers who had previously worked in the Valleys. It remains a significant contribution to the understanding of the relationship between photography and the Valleys, and at the time also provided Ffotogallery with a counterpoint to the potentially contentious contribution to the Valleys Project by fashion photographer David Bailey.

By the mid 1980's there had been almost two decades of steady development of creative photography in and of Wales, with photography as a creative and independent (non-commercial) activity receiving various forms of advocacy. Ffotogallery had started to publish and distribute its own magazine Ffotoview with the cover of the Spring 1984 issues giving an insight into the concerns of the day including features on 'The Earliest Photography in Wales', 'Alvin Coburn in Harlech', 'The Valleys Project' and the article by Alistair Crawford 'Towards a Welsh Photography'. At the very least, the title of his article suggests that there was a mood at the time that the relationship between Wales and photography was a significant and mature one.

The Valleys had continued to witness the effects of the government's closure of mines throughout the region along with the economic fallout that it brought. Unemployment in the Valleys was high, and three of the project's photographers responded to this through what might be considered a traditional documentary approach, focusing on family life and community. Photographing people became increasingly prominent in the Valleys Project following the miners' strike. Mike Berry, Francesca Odell and Roger Tiley's black-and-white work took the form of photo-essays, with Berry focusing on the life of a former mining village at Glyncorrwg, Odell on the younger generation and their aspirations, and Tiley on miners, their families and supporters.

The fourth contributor to this phase, Peter Fraser, was, in terms of his photographic practice, at the opposite end of the scale to the others. His oblique colour images, which he believed acted as psychological triggers, were at the cutting edge of photographic work in Britain at the time. Ffotogallery was increasingly prepared to explore the forms of photography that were moving the boundaries of
10. Susan Beardmore, "The Valleys Project", Ffotoview 7 (Cardiff: Ffotogallery, 1983): 17. 


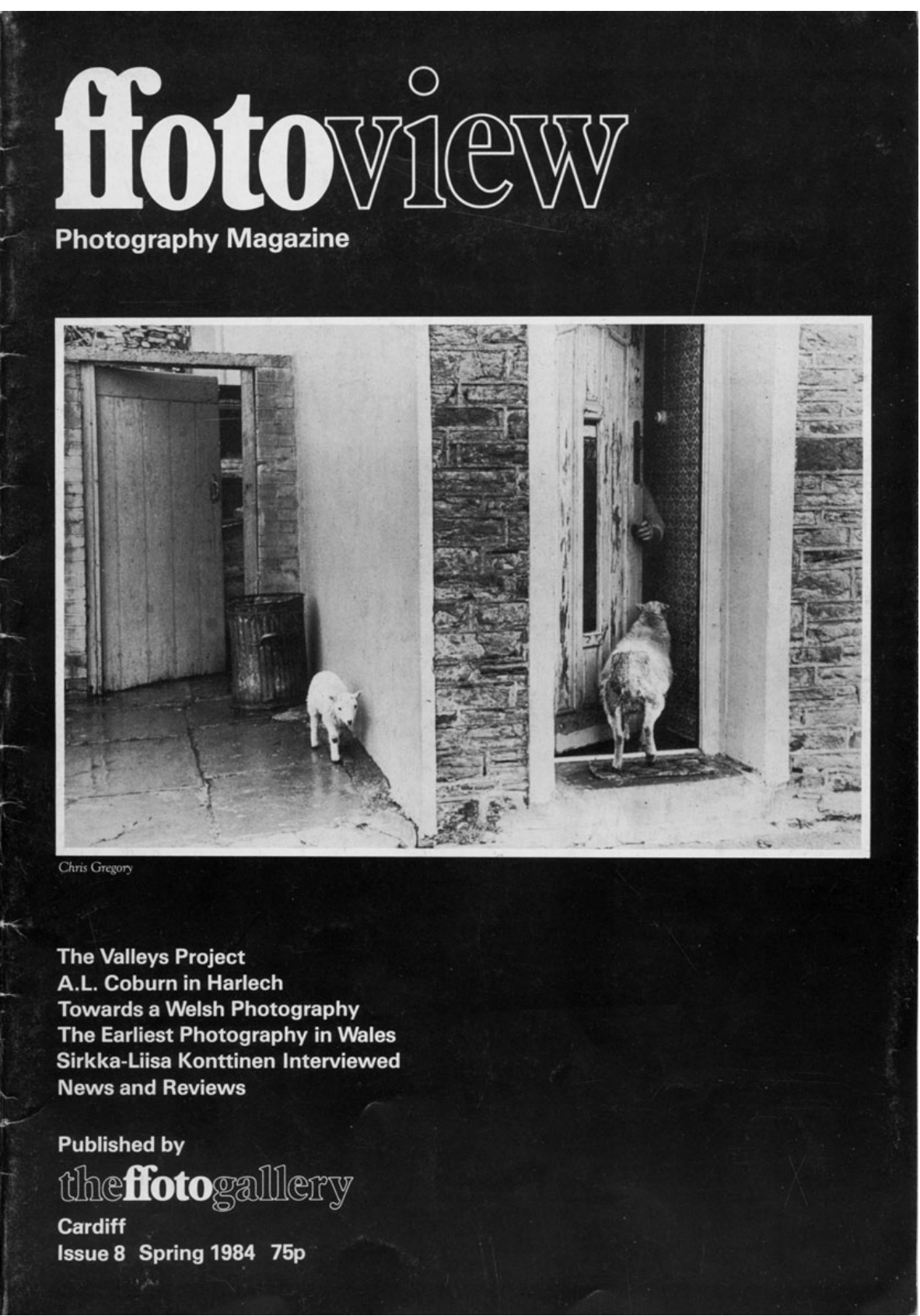

Fig. 1. Ffotoview Magazine cover Issue 8, 1984. @ Ffotogallery

documentary photographic practice, and during 1986 had also exhibited the colour work of photographers Martin Parr (The Last Resort) and Paul Graham (Troubled Land). To some extent, however, it took a risk in showing Fraser's work. As with Bailey's earlier contribution, there was a danger it might seem too detached in the context of the gravitas of a documentary survey like the Valleys Project. Whilst culturally it was exciting for an organization like Ffotogallery to take risks, politically it could have proved difficult in an environment where survival depended on funding from agencies that were themselves politically and culturally accountable.

During the period funds were made available by the British Council and Cardiff City Council to exhibit an edited version of the Valleys Project at the Kulturgemeinschaft in Stuttgart. Cardiff and Stuttgart had been twinned as cities, and both regions had faced similar economic effects of their rapidly shrinking coal industries. This international dimension to the Valleys Project contrasts with the relatively low level of interest in the project in Britain itself. The miners' strike had been dominated the British media, and interest in the subject was exhausted. This, when coupled with the rapidly changing nature of creative photography in Britain during the period, reduced the appeal of a largely regional and traditionally executed documentary project.

British photography was in the process of significant changes, and Ffotogallery's replacement for Susan Beardmore, Christopher Coppock, proved keen to explore photography's creative potential even further. Coppock instigated 'Something Must Be Done', Wally 
Waygood's contribution to the Valleys Project, in October 1989. Coppock was interested in presenting contemporary photography outside a gallery context, with the result that Waygood produced an image for a billboard located at Dowlais Top in Merthyr Tydfil. The site was where Edward Malindine had photographed King Edward VIII touring a derelict steelworks in 1936 and where, on seeing the terrible conditions in Merthyr Tydfil, the King had declared: 'Something must be done.' Malindine's photograph, originally published in the Daily Herald, had been included in the review of photographers featured in Ian Walker's Valley Visitors.

In what would become the final contribution to the Valleys Project, Port Talbot- based William Tsui was commissioned to photograph the communities of Abergwynfi and Blaengwynfi. For all that photography in Britain had been transformed during the 1980s, Tsui's exhibition in 1990 was produced adopting a largely traditional photographic approach. His portrait of two small villages was made up of semiformal portraits of the people living there. Although the Valleys Project would be re-presented by Ffotogallery in 1994, it ceased generating new work after William Tsui's contribution. ${ }^{11}$

In 2015 Ffotogallery's website featured an overview of the Valleys Project that stated:

Many other satellite activities have sprung up as a result of these major photographic initiatives, which have embraced historical research and archival gathering, workshops with local community groups, and courses and classes in schools exploring regional

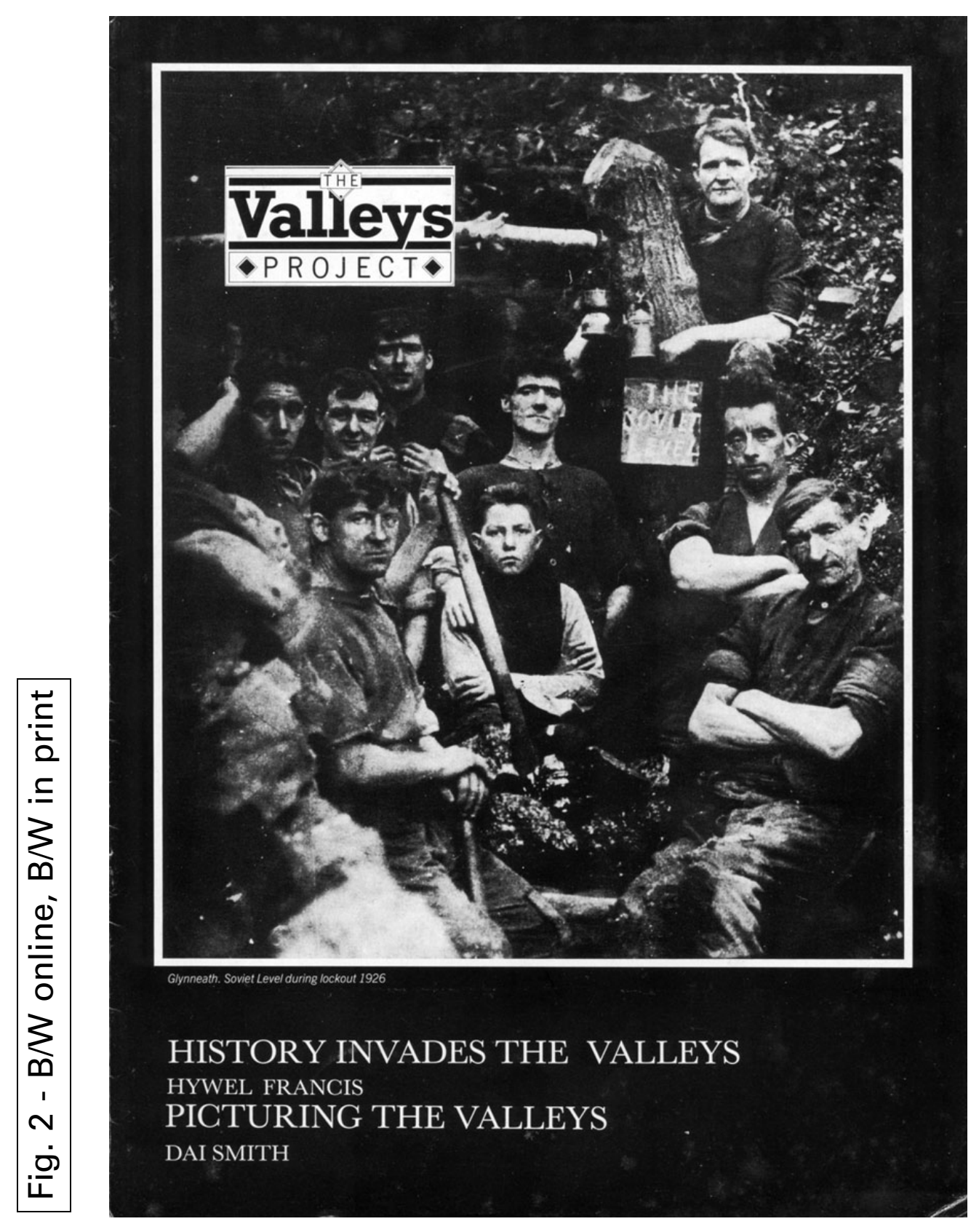

Fig. 2. Valleys Project exhibition booklet cover, 1985. (c) Ffotogallery 
heritage and identity. Photographs from the project have been shown in a wide variety of venues: schools, community centres, art galleries and museums.

Now that the Valleys Project is complete the collection forms an extraordinary portrait of areas in South Wales laden with history. All photographs made for the Valleys Project, over 450 in all, which forms part of Ffotogallery's archive is available for loan and research to schools, colleges, community groups and gallery members. ${ }^{12}$

\section{Materiality of The Valleys Project Archive}

Information was collected in the form of an index during a survey of the Valleys Project Archive that took place between January and March 2004 at Ffotogallery's Library and Members' Room within the Chapter Arts Centre in Cardiff, where the Archive was located. Created by Paul Cabuts, the index described the extant material and did not attempt to deal with the social, historical or cultural significance of the Valleys Project.

The rudimentary index offered a guide to the visual and textual material held in the Archive. Whilst it was important to highlight the context in which the material was found during the survey of the Archive, it was equally important to consider the forms in which the material was originally disseminated through its exhibition and publication. The index therefore presented the material chronologically, with the photographs being grouped into the five exhibitions represented in the Archive.

In total there were 420 photographic prints in the Archive. These were stored in a series of similar black clamshell type archival boxes of which fifteen were $50.5 \times 40.5 \mathrm{~cm}$ size and two at $65.5 \times 55.5 \mathrm{~cm}$ size. In addition to this there was one brown archival box of $65.5 \times 55.5 \mathrm{~cm}$ size. The photographs represent the work of sixteen photographers with the vast majority of the prints being made on black \& white fibre-based paper. Some of the early prints made for the Project were made on black \& white resin coated paper and one set of photographs, made by Peter Fraser for the 1986 exhibition, offer the only colour prints in the Archive. All but four of the prints in the Archive were
12. "Ffotogallery What's On", accessed July, 2015, http://www. ffotogallery.org/whats-on/ the-valleys-archive.

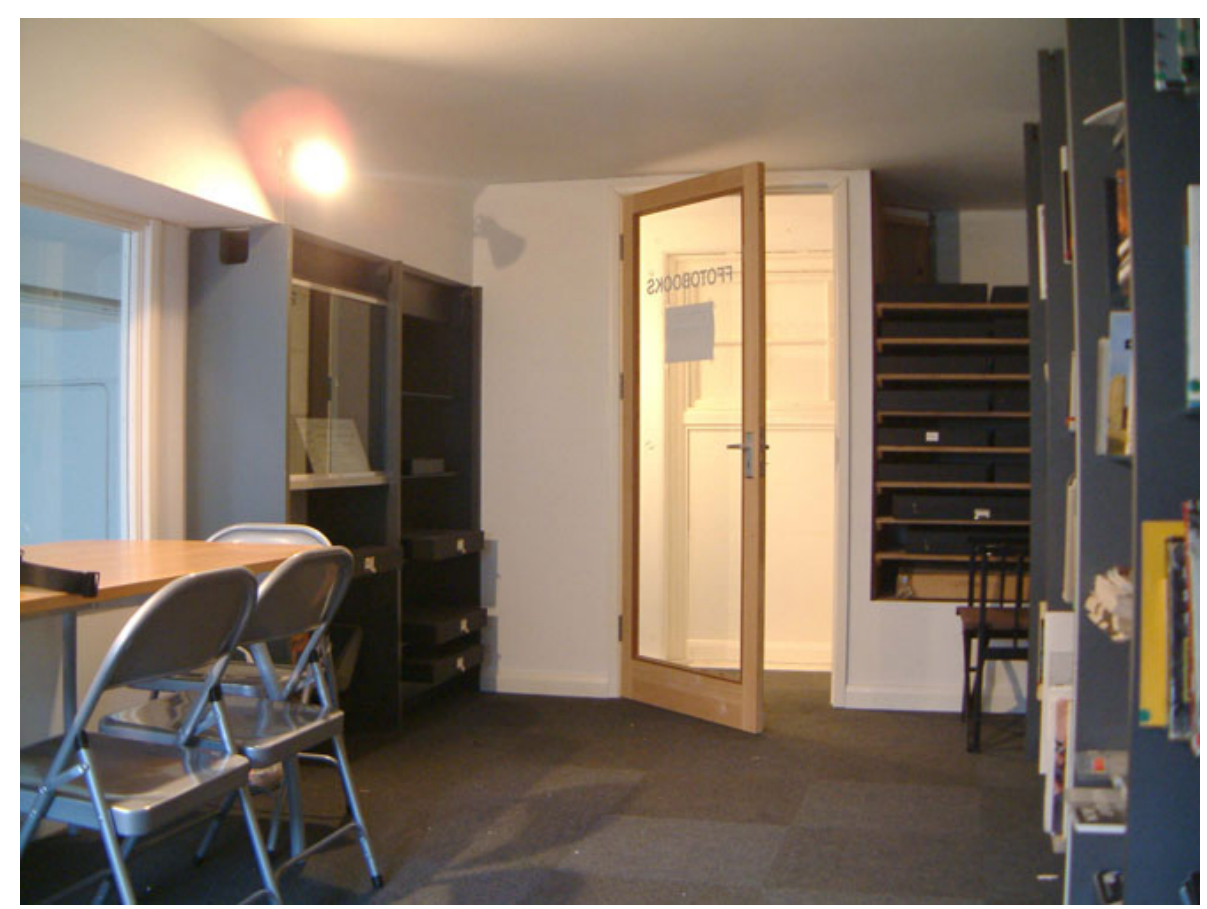

Fig. 3. Ffotogallery Library Room, 2004. (c) Paul Cabuts 
found in window mounts, presumably the ones in which they were framed and exhibited.

The nine publications held in Ffotogallery's Library that are directly linked to the Valleys Project should also be considered as part of the Archive. They were, in the main, exhibition catalogues of varying size and design. The publications produced for the second exhibition, for example, takes the form of four pamphlets presented in a folding wallet. The publication for David Bailey's contribution takes the form of a softback booklet. The texts throughout were written in English only, with the key essays being contributed by Hywel Francis (3), Dai Smith (2), Ian Walker (1) and Richard G. Keen (1). Susan Beardmore, the Ffotogallery Director from 1984 to 1988, made several important written contributions, and for the second exhibition the photographers John Davies, Ron McCormick and Paul Reas also provided texts. The Ffotogallery magazines Ffotoview offered considerable information about the Project in its early stages with issue 8 arguably being the most informative. Other issues featured the Project; these were issues $7,9,10 / 11 \& 12$. The nine publications listed in the index were dispersed across the library at the time of the 2004 survey of the Valleys Project Archive.

\section{Conclusion}

The Valleys Project provides valuable information about the region as it was rapidly entering its post-industrial phase. The passage of time continues to increase its value as a social document although its importance in understanding the rapid transformation of British photography during the 1970 s and 1980 s arguably remains under-exploited.

The Project's ongoing influence in terms of the development of photography in Wales is palpable. During 2011 Ffotogallery invited applications for Two Artist Residencies in South Wales with a focus on the Valleys. During 2013 an exhibition brought together contemporary, historical and vernacular photography, which has the south Wales' Valleys and its communities as its subject. 'The Valleys Re-Presented' examined different visual narratives and typologies and how the currency of images creates and sustains particular mythologies about

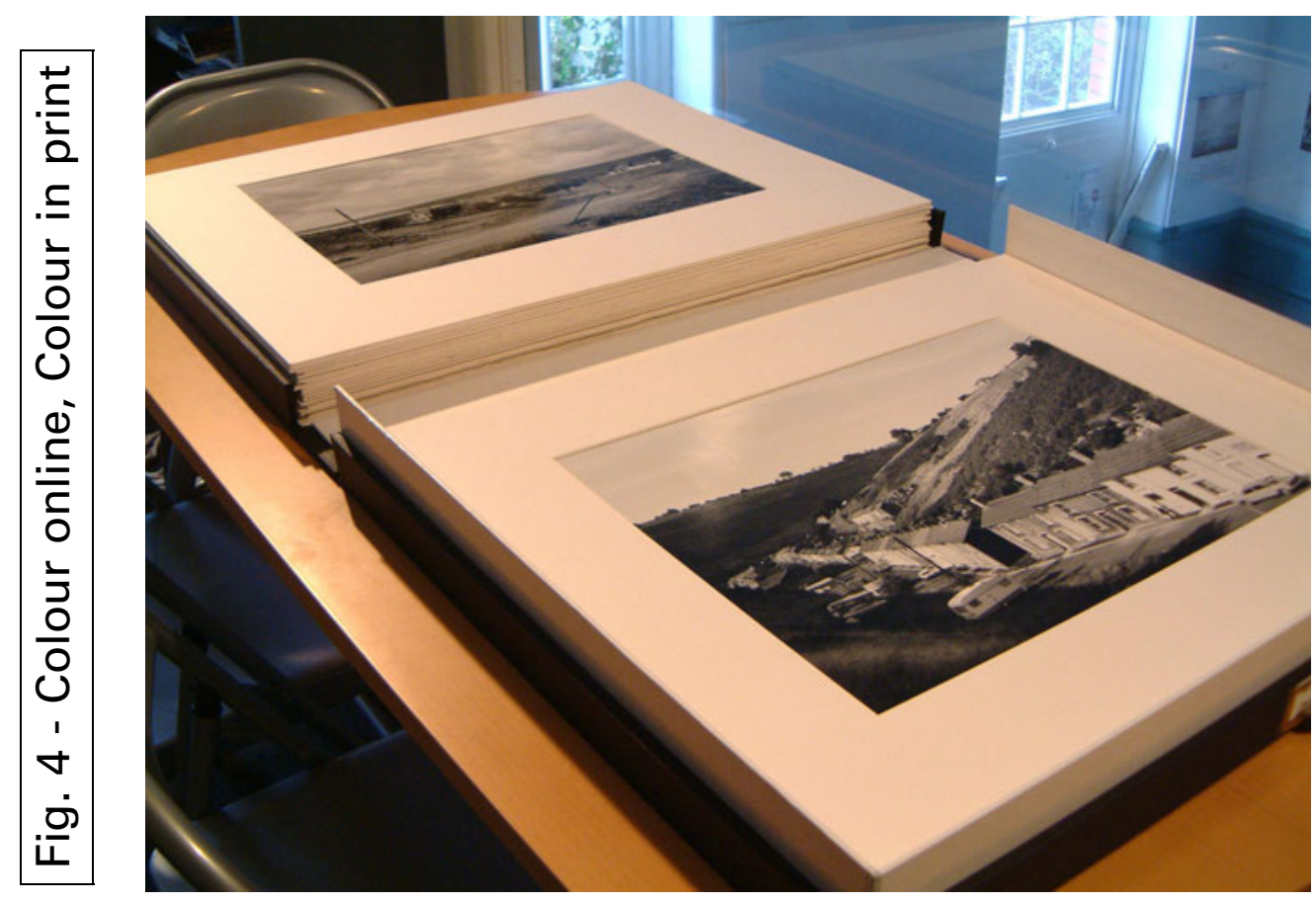

Fig. 4. Valleys Project portfolio box, 2004. (C) Paul Cabuts 
people and place. The exhibition, that included some of the original work from the Valleys Project, was part of Diffusion: Cardiff International Festival of Photography. ${ }^{13}$

\section{Q1 Paul Cabuts}

Director, Institute of Photography

Falmouth University

Penryn Campus, Penryn

Cornwall, TR10 9FE, UK

Email:paul.cabuts@falmouth.ac.uk
13. "Diffusion Festival Programme", accessed July, 2015, http://2013.diffusionfestival. org/programme-item/ the-valleys-re-presented/. 